\title{
PRAKTIK UPAH JASA PENGGILINGAN PADI KELILING PERSPEKTIF HUKUM ISLAM
}

\author{
Rafica Oktaviani ${ }^{1 *}$ Niswatul Hidayati $^{2 *}$ \\ 1,2 Fakultas Syariah, IAIN Ponorogo \\ 1Email: raficaoktaviani210@gmail.com \\ 2Email: niswah.sasmito@gmail.com
}

DOI:

Received: 2-8-2021

Revised: 17-8-2021

Approved: 30-8-2021

Abstract: This research departs from the community's problem of taking rice bran as an additional wage for mobile rice milling services. The purpose of this study focuses on the phenomenon of wages (Ijarah) for mobile rice mill services, which is then analyzed based on the perspective of Islamic law. The type of research used is field research using qualitative research methods and data collection techniques through interviews. In this study, it was found that the wages of the mobile rice milling contract in Gegeran Sukorejo Ponorogo Village were not entirely following Islamic law because the determination of wages was only carried out by one party and taking additional wages in the form of rice bran without any openness and willingness from the farmers, thus harming one of the farmers. Parties, namely farmers or consumers. Regarding the Ijarah agreement, the mobile rice mill service in Gegeran Sukorejo Village, Ponorogo, is not entirely following Islamic law because the transaction does not fulfil the principles in the contract, especially the principle of ibahah, the principle of trust (honesty), fairness and balance of achievements. Although in the transaction between the two, there is a valid qabul ijāb.

Keywords: Ijarāh, Islamic Law, Milling Services, Salary

Abstrak: Penelitian ini berangkat dari problem masyarakat terkait pengambilan bekatul sebagai tambahan upah jasa penggilingan padi keliling. Tujuan penelitian ini memfokuskan terhadap fenomena upah (Ijarah) jasa penggilingan padi keliling yang kemudian dianalisis berdasarkan perspektif hukum Islam. Jenis penelitian yang digunakan adalah penelitian lapangan (Field research) dengan menggunakan metode penelitian kualitatif dan teknik pengumpulan data melalui wawancara. Dalam penelitian ini ditemukan bahwa upah akad penggilingan padi keliling di Desa Gegeran Sukorejo Ponorogo belum sepenuhnya sesuai dengan hukum Islam, karena penetapan upah hanya dilakukan oleh salah satu pihak dan pengambilan penambahan upah berupa bekatul tanpa adanya keterbukaan dan kerelaan dari pihak petani, sehingga merugikan salah satu pihak yakni petani atau konsumen. Terkait Akad ijarah jasa penggilingan padi keliling di Desa Gegeran Sukorejo Ponorogo belum sepenuhnya sesuai dengan hukum Islam karena dalam transaksi tersebut tidak 
memenuhi asas-asas dalam berakad, khususnya asas ibahah, asas amanah (kejujuran), keadilan dan keseimbangan prestasi. Meskipun dalam transaksi antara keduanya terdapat ijāb qabūl yang sah.

Kata Kunci: Hukum Islam, Ijarāh, Jasa Penggilingan, Upah

\section{PENDAHULUAN}

Pada transaksi muamalah, manusia membutuhkan alat tukar yaitu uang. Dalam berinteraksi tersebut satu sama lain terjadi sebuah akad (transaksi) untuk memenuhi kebutuhan hidupnya. Kesepakatan transaksi dalam Islam disebut akad, sedangkan dalam hukum Indonesia disebut dengan perjanjian. ${ }^{1}$ Kata akad berasal dari kata al-'aqd yang berarti mengikat, menyambung, atau menghubungkan. ${ }^{2}$

Adapun praktik perdagangan baik dalam skala besar maupun kecil, akad merupakan bentuk transaksi yang melibatkan dua atau banyak pihak, yang sedikit banyak tidak terlepas dari persoalan Ijarah dalam syariat Islam. ${ }^{3}$ Salah satu bentuk akad Ijarah yaitu praktik penggilingan padi atau gabah.

Bagi masyarakat padi menjadi komoditas yang sangat penting, tidak saja dilihat dari sisi produsen tetapi juga dari sisi konsumen. Sebelum menjadi beras, padi akan melalui beberapa tahap pascapanen yaitu: pemanenan padi, penyimpanan padi, perontokan padi, pengeringan padi, pengilingan gabah hingga menjadi beras. Masalah utama yang sering dihadapi petani dari proses pascapanen padi tersebut adalah menyusutnya hasil panen dari yang diharapkan. ${ }^{4}$

Penggilingan padi keliling yang berada di Desa Gegeran Sukorejo Ponorogo, seperti pada umumnya di pedesaan. Jasa ini berkeliling ke kampung-kampung untuk menawarkan jasa penggilingan padi. ${ }^{5}$ Dalam praktiknya, masyarakat Desa Gegeran biasa menunggu kedatangan penggiling padi yang berkeliling atau menghubungi langsung pihak penggiling padi. Biaya penggilingan disediakan oleh penyedia jasa dan takaran yang digunakan adalah karung. Awalnya harga satu

${ }^{1}$ Lukman Santoso, Hukum Perikatan (Malang: Setara Press, 2016).

2 Syamsul Anwar, Hukum Perjanjian Syariah (Jakarta: Rajawali Press, 2010), 68.

3 Husain Insawan, "Al-Ijarah dalam perspektif Hadits, Kajian Hadits dengan Metode Maudhu'iy," Fakultas Ekonomi dan Bisnis Islam IAIN Kendari 2, nomor 1 (Juni 2017): 138, https://garuda.ristekbrin.go.id/documents/detail/2041350.

4 Sartika Novi Dewi dan Zuhriyah Ramdhani, "Kajian Penggunaan Mesin Penggiling Mobile Terhadap Mutu Beras Untuk Beberapa Varietas Padi Di Kabupaten Sumbawa Barat," Jurnal Ilmiah Rekayasa Pertanian dan Biosistem, 6 (1 Maret 2018), https://doi.org/10.29303/jrpb.v6i1.72. Gegeran.

5 . Anwariyah, wawancara dengan pemilik padi atau gabah di Desa Gegeran, 29 Juli 2020, Desa 
karung padi dipatok Rp 5000/karung (urea) ditambah 1 gayung bekatul Rp 8000Rp 10.000 ditambah 1 gayung bekatul, namun berubah menjadi Rp 12.000 per karung tanpa bekatul . ${ }^{6}$

Meskipun sudah di jelaskan bahwa seluruh hasil dari penggilingan padi adalah milik petani, namun jika petani melakukan jasa penggilingan padi petani hanya mendapat beras dan dedak sedangkan bekatul sisa penggilingan tersimpan di mesin penggilingan dan dimanfaatkan oleh penggiling. Bekatul biasanya digunakan petani untuk pakan ternak atau untuk sumber pendapatan tambahan karena dapat dijual kembali dengan harga Rp. 3.000-Rp. 4.000 per kilogram. ${ }^{7}$

Berpijak dari dinamika tersebut peneliti tertarik untuk menelaah lebih lanjut mengenai hal tersebut. Karena berdasarkan telaah peneliti, topik tersebut unik sekaligus belum ada penelitian yang mengulas persoalan akad tersebut. Hal ini setidaknya dapat dibuktikan dari beberapa penelitian yang mengulas seputar topik upah maupun jasa penggilingan padi.

Berikutnya penelitian Afriza, ${ }^{8}$ berjudul "Tinjauan Hukum Islam Tentang Pengupahan Penggilingan Padi dengan beras." Penelitian tersebut menjelaskan bahwa sistem pengupahan yang dilakukan petani dan pihak pabrik di Desa Sukajaya Katibung Lampung Selatan adalah praktik pengupahan yang dilakukan dengan mengikuti adat kebiasaan di Desa Sukajaya telah memenuhi rukun dan syarat dalam pengupahan, dimana sistem pengupahannya setiap $10 \mathrm{~kg}$ beras dibayar dengan $1 \mathrm{~kg}$ beras. Tinjauan hukum Islam tentang pengupahan penggilingan padi dengan beras di Desa Sukajaya Katibung Lampung Selatan adalah praktik upah mengupah yang sesuai dengan hukum Islam karena sudah menjadi adat kebiasaan masyarakat Desa Sukajaya, pada dasarnya praktik pengupahan penggilingan padi menggunakan beras mengandung unsur tolong menolong. Namun akan lebih baik ketika pemotongan berlangsung kedua belah pihak menghadiri secara langsung untuk menghindari hal-hal yang tidak diinginkan dan dapat merugikan kedua belah pihak.

6Siti Fatimah, Wawancara Dengan Pemilik padi atau Gabah, Agustus 2020, Desa Gegeran. ${ }^{7}$ wawancara dengan pemilik padi atau gabah padi keliling di Desa Gegeran.

${ }^{8}$ Afrizal, "Tinjauan Hukum Islam Tentang Pengupahan Penggilingan Padi Dengan Beras" (Skripsi, Lampung, Universitas Islam Negeri Raden Intan Lampung, 2017), http://repository.radenintan.ac.id/3100/.x 
Penelitian berikutnya ditulis Ratna Kartika,9 berjudul "Tinjauan Hukum Islam Terhadap Praktek jasa Penggilingan padi Keliling di Desa Purworejo Kecamatan Geger Kabupaten Madiun.” Penelitian tersebut menjelaskan akad jasa penggilingan padi keliling di Desa Purworejo Geger Madiun belum sepenuhnya sesuai dengan hukum Islam, karena dalam transaksi tersebut tidak memenuhi ketentuan asas-asas dalam berakad meskipun terdapat ijab qabul yang sah antar kedua belah pihak. Sistem pembayaran jasa penggilingan padi keliling dengan penetapan harga yang berbeda-beda belum sepenuhnya sesuai dengan hukum Islam, karena tidak ada ketetapan harga yang pasti. Khususnya dalam penetapan harga selep dan pengambilan upah berupa beras. Sehingga merugikan satu pihak yakni konsumen atau masyarakat. Status kepemilikan sisa beras yang ada di mesin penggilingan adalah sesuai dengan hukum Islam, hal ini terbukti karena tidak adanya nilai ekonomi pada sisa beras yang ada pada mesin penggilingan tersebut. Sehingga tidak ada pihak yang dirugikan.

Berangkat dari berbagai penelitian tersebut, maka penelitian ini hanya akan fokus pada pertanyaan terkait bagaimana tinjauan hukum Islam terhadap upah jasa penggilingan padi keliling dan akad ijarah jasa penggilingan padi keliling tersebut di Desa Gegeran Sukorejo Ponorogo.

Penelitian ini merupakan studi lapangan, dengan menggunakan pendekatan kualitatif. Menurut Denzin dan Lincoln, bahwa penelitian kualitatif adalah penelitian yang menggunakan latar alamiah dengan maksud menafsirkan fenomena yang terjadi dan dilakukan dengan jalan melibatkan berbagai metode yang ada. ${ }^{10}$ Penelitian ini berlokasi di Desa Gegeran Kecamatan Sukorejo Kabupaten Ponorogo dengan pendekatan empiris. Pendekatan empiris adalah pendekatan yang keberadaannya dapat dibuktikan pada alam kenyataan atau dapat dirasakan oleh panca indra. ${ }^{11}$

${ }^{9}$ Ratna Kartikasari, “Tinjauan Hukum Islam Terhadap Praktek Jasa Penggilingan Padi Keliling Di Desa Purworejo Kecamatan Geger Kabupaten Madiun" (Skripsi, Sekolah Tinggi Agama Islam Negeri (STAIN) Ponorogo, 2016); “Tinjauan Hukum Islam Tentang Pengupahan Penggilingan Padi Dengan Beras."2.

${ }^{10}$ Johan Setiawan dan Albi Anggito, Metode Penelitan Kualitatif (Jawa Barat: CV Jejak, t.t.).7.

${ }^{11}$ Depri Liber Sonata, "METODE PENELITIAN HUKUM NORMATIF DAN EMPIRIS: KARAKTERISTIK KHAS DARI METODE MENELITI HUKUM," FIAT JUSTISIA: Jurnal Ilmu Hukum 8, no. 1 (5 November 2015), https://doi.org/10.25041/fiatjustisia.v8no1.283.24. 


\section{KONSEP IJARAH DAN AKAD TRANSAKSI BISNIS}

Istilah Ijarah berasal dari kata bahasa Arab ajara-ya'juru-ajran, yang semakna dengan kata al-'iwadh yang mempunyai arti ganti dan upah. Secara Syar'I Ijarah adalah akad manfaat yang mubah lagi diketahui yang diambil sedikit demi sedikit selama masa tertentu dari barang yang diketahui atau barang yang diberi criteria dalam tanggungan, atau (akad) atas pekerjaan tertentu dengan upah tertentu. ${ }^{12}$

Terdapat beberapa definisi ijarah menurut para ahli. Pertama, Ulama Hanafiyah menyatakan ijarah adalah transaksi terhadap suatu manfaat dengan imbalan/fee/penukar manfaat. Kedua, Ulama Syafiiyah memberikan pernyataan mengenai ijarah adalah transaksi terhadap manfaat tertentu yang dibolehkan, dapat digunakan dan dengan imbalan (bayaran) tertentu. Ketiga, Ulama Malikiyah dan Hanabilah menyatakan bahwasanya ijarah adalah kepemilikan manfaat atas sesuatu yang dibolehkan, dalam waktu tertentu dengan imbalan (bayaran) tertentu.

Keempat, sedangkan menurut Jumhur Ulama Fiqih menyatakan bahwasanya ijarah ialah menjual manfaat, sehingga yang boleh disewakan adalah manfaatnya, bukan bendanya. Berdasarkan hal tersebut dilarang menyewakan kambing untuk diambil susu, lemak ataupun bulunya ataupun dilarang menyewa sumur dan sungai untuk diambil airnya. Kelima, menurut Fatwa DSN MUI No:09/ DSN-MUI/IV/2000 dan No: 112/ DSN- MUI/IX/2017 menyatakan bahwasannya ijarah adalah akad pemindahan hak guna (manfaat) atas suatu barang atau jasa dalam waktu tertentu melalui pembayaran sewa/upah, tanpa diikuti dengan pemindahan kepemilikan barang itu sendiri. Akad ijarah adalah akad sewa antara mu'jir dengan musta'jir atau antara musta'jir dengan $a$ 'jir untuk mempertukarkan manfaah dan ujrah, baik manfaat barang maupun jasa. ${ }^{13}$

Dalil pensyariatan Ijarah terdapat dalam Firman Allah Surat Ath- Thalaq ayat 6 dijelaskan bahwa "kemudian jika mereka menyusukan (anak-anak kalian) untuk kalian, maka berikanlah kepada mereka upah mereka" dan Firman Allah

12 Tim Ulama Izzudin Karimi, Fikih Muyassar Panduan Praktis Fikih dan Hukum Islam, 387 (Jakarta: Tim Darul Haq, 2019). 387.

13 Andri Soemitra, Hukum Ekonomi Syariah Dan Fiqh Muamalah Di Lembaga Keuangan dan Bisnis Kontemporer (jakarta Timur: PRENADA MEDIA GROUP, 2019).116. 
SWT dalam surat Al-Qashas ayat 26 dijelaskan bahwa "salah seorang dari kedua wanita itu berkata' wahai bapak, sewalah dia sebagai orang yang bekerja (pada kita), karena sesungguhnya orang yang paling baik yang kamu sewa untuk bekerja (pada kita) ialah orang yang kuat lagi dapat dipercaya. Dari ibnu Umar Ra dia berkata “ Berikanlah Upah kepada pekerja sebelum kering keringatnya” 14

Adapun rukun Ijarah terdiri dari Mu'jir dan Musta'jir, yaitu orang yang melakukan akad sewa-menyewa atau upah mengupah. $M u^{\prime} j i r$ adalah orang yang menerima upah dan yang menyewakan, Musta'jir adalah orang yang menyewa, disyaratkan pada $M u^{\prime} j i r$ adalah baligh, berakal, cakap, dan melakukan tasharuf (mengendalikan harta dan saling meridhoi), Tentang hal ini dijelaskan dalam surat surat an-nisa ayat 29 berikut, "Hai orang-orang yang beriman, janganlah kamu saling memakan harta sesamamu dengan jalan batil kecuali dengan perniagaan yang berlaku dengan suka sama suka diantara kamu."15

Transaksi dalam konteks fiqh muamalah dapat disebut dengan akad. Kata akad berasal dari bahasa Arab al-'aqd bentuk jamaknya al-'uqud. ${ }^{16}$ Yang mempunyi arti antara lain: Pertama, Mengikat (Arobtu), yaitu: mengumpulkan dua ujung tali dan mengikat salah satunya dengan yang lain sehingga bersambung, kemudian keduanya menjadi sepoton benda. ${ }^{17 K e d u a, ~ S a m b u n g a n ~(' a q d a t u n), ~ y a i t u: ~}$ sambungan yang memegang kedua ujung itu dan mengikatnya. ${ }^{18}$ Ketiga, Janji ('ahdun), yaitu: “...sebenarnya siapa yang menepati janji (yang dibuat)nya dan bertaqwa. Maka sesungguhnya Allah menyukai orang-orang yang bertaqwa."19

Dari uraian diatas dapat dipahami bahwa setiap perjanjian dalam akad persetujuan mencakup tiga tahap, yaitu:

1) Perjanjian ('ahdu)

2) Persetujuan dua buah perjanjian atau lebih

3) Perikatan

\footnotetext{
14 Izzudin Karimi, Fikih Muyassar Panduan Praktis Fikih dan Hukum Islam. 387-388

${ }^{15}$ Wahbah Zuhaili, Tafsir Al-Munir, Juz 5 \& 6 (Jakarta: Gema Insani, 2016), https://id1lib.org/book/5228264/2a9ad4?dsource=recommend.,84

16 Qomarul Huda, Fiqih Muamalah (Yogyakarta: Teras, 2011).25

${ }^{17}$ Hendi H Suhendi, Fiqh Muamalah: Membahas Ekonomi Islam Kedudukan Harta, Hak Milik, Jual Beli, Bunga Bank Dan Riba, Musyarakah, Ijarah, Mudayanah, Koperasi, Asuransi, Etika Bisnis Dan Lain- Lain (Jakarta: PT RajaGranfindo Persada, 2002).44.

${ }^{18}$ Suhendi.

${ }^{19}$ Huda, Fiqih Muamalah.26
} 
Sementara menurut istilah (terminologi), yang dimaksud dengan akad adalah "perikatan ijab dan qabul yang dibenarkan syara' yang menetapkan keridhoan kedua belah pihak."20

Dari beberapa uraian diatas disimpulkan bahwa akad adalah suatu perikatan antara ijab dan qabul dengan cara yang dibenarkan syara' yang menetapkan adanya akibat-akibat hukum pada objeknya. ${ }^{21}$ Dalam akad pada dasarnya dititik beratkan pada kesepakatan antara dua belah pihak yang ditandai dengan ijab qabul. Ijab adalah pernyataan pihak pertama mengenai isi perikatan yang diinginkan, sedang qabul adalah pernyataan pihak kedua untuk menerimanya. ${ }^{22}$

Dalam hukum Islam terdapat beberapa asas akad yang berpengaruh kepada pelaksanaan akad yang dilaksanakan oleh pihak-pihak yang berkepentingan, berikut penjelasannya.

\section{a. Asas Ibahah}

Asas ibahah adalah asas umum hukum Islam dalam bidang muamalat secara umum. Asas ini dirumuskan berdasarkan kaidah fiqh: “ pada asasnya segala sesuatu itu boleh dilakukan sampai ada dalil yang melarangnya. ${ }^{23}$ Asas ini merupakan kebalikan dari asas yang berlaku dalam masalah ibadah. Dalam hukum Islam untuk tindakan-tindakan Ibadah berlaku asas bahwa bentuk-bentuk Ibadah yang sah adalah bentuk-bentuk yang disebutkan dalam dalil-dalil syari'ah. Sedangkan, dalam tindakan-tindakan muamalaat berlaku asas sebaliknya, yaitu bahwa segalaa sesuatu itu sah dilakykan sepanjang tidak ada larangan tegas atas tindakan itu. ${ }^{24}$

b. Asas kebebasan berkontrak

Asas kebebasan berkontrak didasarkan firman Allah dalam surat Maidah ayat 1 , kebebasan berkontrak pada ayat ini disebutkan dengan kata "akad-akad" atau dalam teks aslinya adalah al-'uqud, yaitu bentuk jamak menunjukkan keumuman artinya orang boleh membuat macam-macam perjanjian-perjanjian itu

\footnotetext{
${ }^{20}$ Huda.

${ }^{21}$ Suhendi, Fiqh Muamalah.46

22 Suhendi.

${ }^{23}$ Anwar, Hukum Perjanjian Syariah.83.

${ }^{24}$ Anwar.
} 
dan wajib dipenuhi akan janji tersebut. Namun kebebasan berkontrak dalam hukum Islam ada batas-batasannya yakni sepanjang tidak makan harta sesama dengan jalan batil. Sebagaimana dijelaskan dalam Surat An-Nisa' ayat 29 bahwa: hai orang-orang yang beriman, janganlah kamu saling memakan hartaa sesamamu dengan jalan batil, kecuali dengan jalan perniagaan yang berlaku dengan suka sama suka di antara kamu. Dan janganlah kamu membunuh dirimu. Sesungguhnya Allah adalah maha penyayang kepadamu. ${ }^{25}$

c. Asas janji itu mengikat

Dalam Al-Qur'an dan Hadits terdapat banyak perintah agar memenuhi janji. Dalam kaidah usul fiqh, "perintah pada dasarnya menunjukkan wajib". Ini berarti bahwa janji itu mengikat dan wajib dipenuhi. ${ }^{26}$ Asas perjanjian itu mengikat dalam Al-Qur'an seperti pada surat Al-Imran ayat 34 bahwa “(sebagai) satu keturunan yang sebagiannya (turunan) dari yang lain. Dan Allah maha mendengar lagi maha mengetahui." 27

d. Asas Konsesualisme

Asas konsesualisme juga didasarkan surat An-Nisa ayat 29 yang telah dikutip di atas yakni atas dasar kesepakatan bersama.

e. Asas Kedilan dan Keseimbangan Prestasi

Asas keadilan dan keseimbangan prestasi merupakn asas yang menegakkan pentingnya kedua belah pihak agar tidak saling merugikan . transaksi harus didasarkan keseimbangan antara apa yang dikeluarkan oleh satu pihak dengan apa yang diterima.

f. Asas Amanah (kejujuran)

Asas kejujuran dan amanah dalam bermuamalah menekankan pentingnya nilai-nilai etika di mana orang harus jujur, transparan dan menjaga amanah. ${ }^{28}$

\section{PRAKTIK UPAH DAN AKAD JASA PENGGILINGAN PADI KELILING DI DESA GEGERAN}

Dalam kehidupan sehari-hari, fenomena pengupahan merupakan fenomena yang lekat dengan interaksi dan relasi antar individu dan kelompok dalam

\footnotetext{
25 Anwar.

${ }^{26}$ Anwar. 83.

27Zuhaili, Tafsir Al-Munir.55

${ }^{28}$ Anwar, Hukum Perjanjian Syariah.., 84
} 
masyarakat. Demikian pula dalam kasus praktik upah jasa penggilingan padi di Desa Gegeran yang menggunakan uang. Untuk tarif pengupahan sendiri ditentukan oleh penggiling padi setelah selesai melakukan proses penggilingan. Dalam menentukan harga atau tarif jasa harus adanya kesepakatan antara dua belah pihak, namun dalam penggilingan padi yang dilakukan oleh petani dan penggiling padi ditentukan oleh salah satu pihak yakni pihak penggiling dan diberikan setelah proses penggilingan selesai dengan pihak penggiling menyebutkan nominal penggilingan yang harus dibayar.

Pada tahun 2004 harga yang dipatok dalam upah jasa penggilingan padi ini masih Rp. 5000/karung (urea), namun karena saat itu mengalami krisis bahan bakar, tarif jasa penggilingan juga mengalami kenaikan menjadi Rp. 8000/karung (urea) bahkan ada beberapa yang menerapkan tarif Rp. 10.000/karung (urea). karena ketidaksamarataan harga dalam pengupahan, masyarakat tentunya lebih banyak memilih jasa yang nominal harga lebih murah dan mengakibatkan kesenjangan diantara para penjual jasa. Akhirnya pada awal tahun 2006, para pemilik Huller membentuk suatu organisasi untuk menentukan nominal tarif. Hal tersebut dipertimbangkan dari biaya operasional masing-masing pemilik mesin selep. sehingga masyarakat tinggal mengikuti ketentuan yang berlaku sesuai ketetapan masing-masing pemilik mesin selep. 29

Apabila melihat dari sejarah tarif penggilingan padi keliling di Gegeran, mulanya tarif/upah ditentukan olah pemilik mesin penggilingan, sudah menjadi ketetapan dan adat kebiasaan masyarakat daerah Gegeran, namun hal yang kenaikan dari harga tersebut merupakan upah yang ditanggung petani untuk seluruh proses penggilingan, dan hak petani mendapatkan seluruh hasil dari poses penggilingan

Banyak dari masyarakat yang memberikan respon positif dengan adanya penggilingan padi keliling. Karena memang memberikan dampak yang lebih baik. Dan banyak macam penggilingan padi yang sering kita jumpai, dan marak sampai saat ini namun hal tersebut juga penggunaan dan manfaatnya pun berbeda dari satu mesin ke mesin yang lain.

\footnotetext{
29Jemari, Wawancara Dengan Pemilik Penggilingan Padi Keliling, Oktober 2020, Desa Gegeran.
} 
Terdapat beragam jenis mesin yang digunakan Agar lapisan bekatul dari beras pecah kulit dan terakhir memoles beras siap dikonsumsi dan memiliki penampakan yang menarik. ${ }^{30}$ Berikut beberapa macam alat penggilingan padi yang digunakan pada saat ini yaitu:

a. Penggilingan padi kecil (PPK)

Penggilingan padi dengan kapasitas produksi kurang dari 1,0 Ton gabah/jam. Rangkaian mesin utamanya terdiri atas Husker dan Polisher yang terpisah satu sama lain sehingga pemindahan gabah pecah kulit dan husker ke polisher dilakukan dengan tenaga manusia.

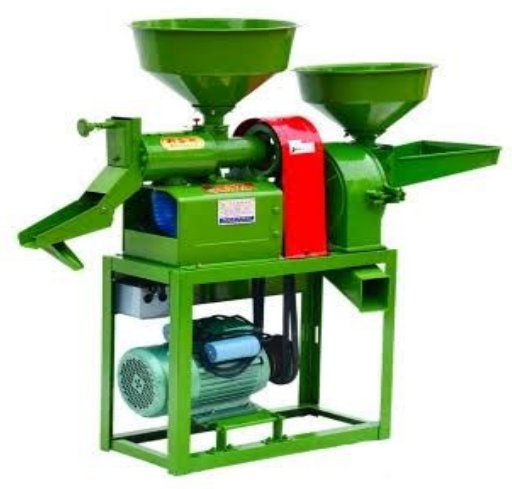

Gambar 3.1 konfigurasi penggilingan padi kecil ${ }^{31}$

b. Rice Milling Unit (RMU)

Penggilingan padi dengan kapasitas kurang dari 1 Ton gabah/jam. Rangkaian mesinnya terdiri atas mesin pecah kulit (husker) dan mesin penyosoh (polisher) yeng menyatu/tidak terpisah sehingga proses dari gabah, langsung keluar menjadi beras putih dengan mutu beras relative rendah.

${ }^{30}$ Hadiutomo Kusno, Membangun Kawasan Persawahan Padi Modern (Bogor: PT Penerbit IPB https://www.google.co.id/books/edition/Membangun_Kawasan_Persawahan_Padi_Modern/E6PVDwAA QBAJ?hl=id\&gbpv=1\&dq=Hadiutomo, + Kusno.Membangun + Kawasan + Persawahan + Padi + Modern\&prin tsec $=$ frontcover. 95

${ }^{31}$ Kusno. 95 


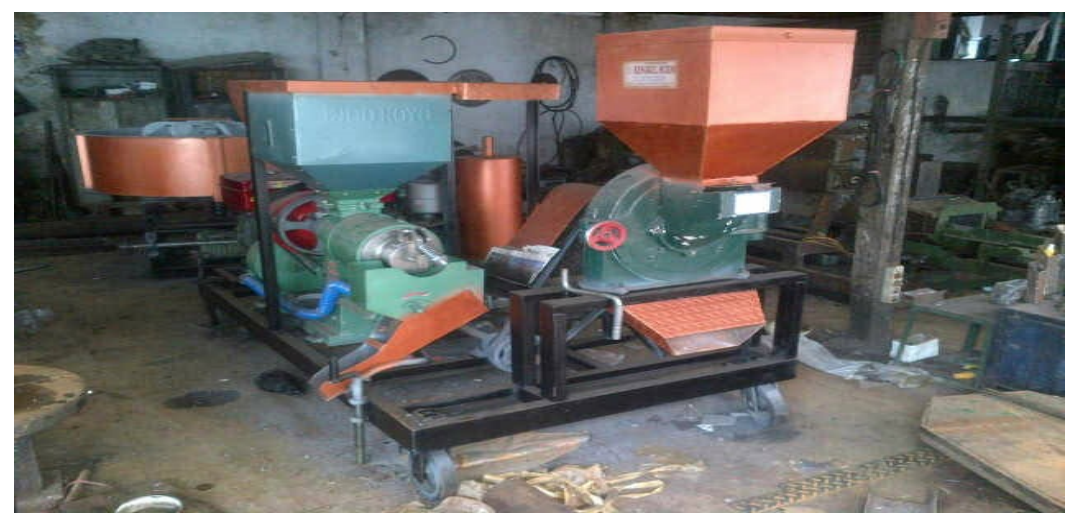

Gambar 3.2 konfigurasi penggilingan padi RMU ${ }^{32}$

c. Penggilingan Padi Menengah (PPM)

Peggilingan padi dua phrase atau lebih dengan kapasitas produksi 1,0-3,0 ton gabah/jam yang rangkaian mesin terdiri dari mesin pembersih gabah (cleaner), mesin pemecah kulit (husker), mesin pemisah gabah (separator), dan mesin penyosoh (polisher) sebanyak dua mesin atau lebih.

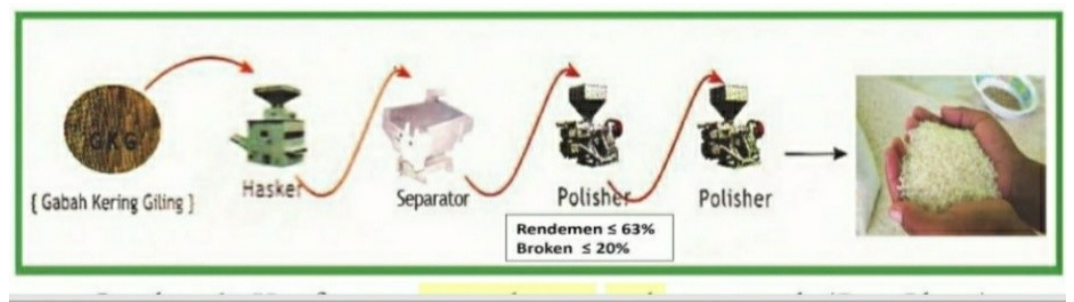

Gambar 3.3 konfigurasi penggilingan padi menengah (duaphase) 33

d. Penggilingan Padi Besar (PPB)

Penggilingan padi tiga phase atau lebih dengan kapasitas produksi lebih besar dari 3,0 ton gabah/jam. Rangkaian mesin minimal terdiri atas mesin pengering vertical (vertical dryer), mesin pembersih (cleaner), mesin pemecah kulit (husker), mesin pemisah gabah (separator), dan mesin penyosoh beras (polisher) sebanyak tiga unit atau lebih, serta mesin pemisah menir(shifter).

32 Kusno.96.

33 Kusno. 


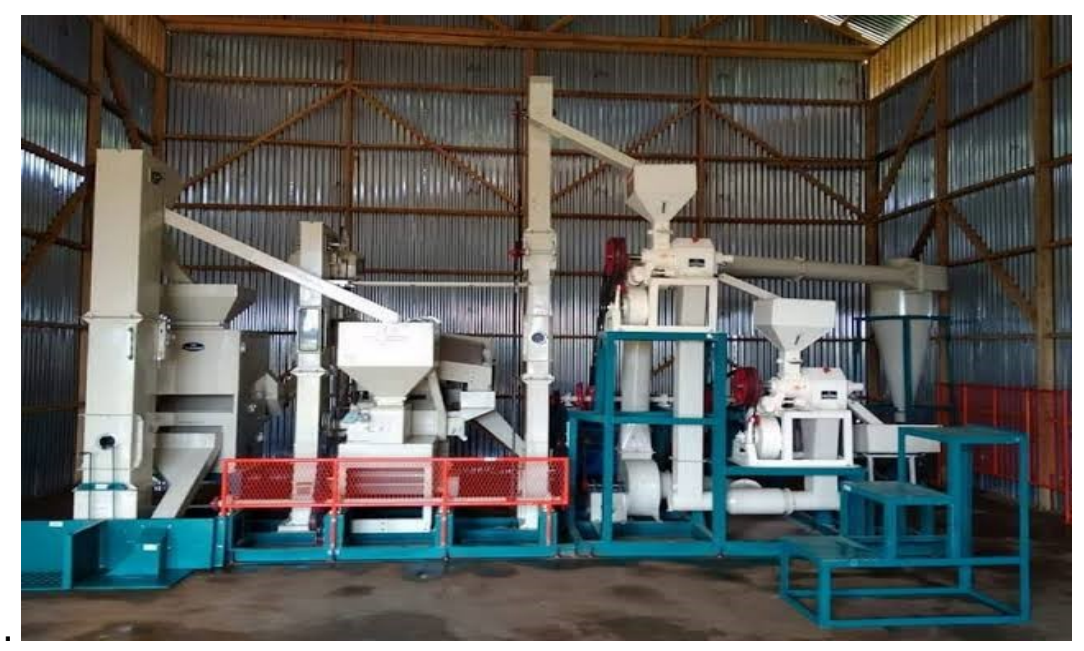

Gambar 3.4 konfigurasi penggilingan padi besar (PBB) ${ }^{34}$

e. Penggilingan Padi Modern (Rice Milling Plant)

Pada penggilingan padi modern secara umum konfigurasi mesin penggilingan padi modern (Rice Milling Plant) ini merupakan suatu rangkaian dari beberapa unit alat mesin yang disusun secara terpadu dan terintegerasi. Dalam konfigurasi ini terdapat mesin utama dan mesin pembantu, yang sifatnya untuk mendukung kelancaran dan fungsi operasional dari rangkaian mesin penggiling padi.

Mesin pembantu umumnya berfungsi untuk transformasi bahan yang diolah dan dihasilkan (baik hasil utama maupun hasil samping), serta berfungsi sebagai penerus daya dari motor penggerak yang digunakan. Mesin-mesin pembantu diataranya, bucket elevator, screw conveyor, belt conveyor, pipa-pipa, blower, compressor, cyclone, porostransmisi, dan lain-lain.

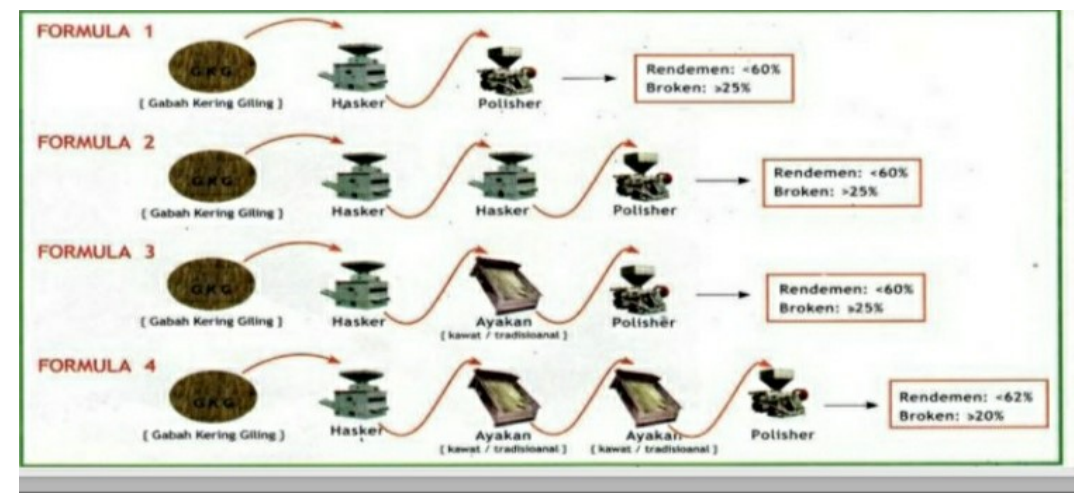

Gambar 3.5 konfigurasi penggilingan padi dari yang terkecil ${ }^{35}$

34 Kusno.. 97 
Tentunya dari sekian tipe penggilingan padi memiliki kelebihan dan kekurangan masing-masing. Namun sampai saat ini mesin pengupas gabah yang masih sering digunakan adalah tipe Rice Milling Unit (RMU) yang mana beberapa tahun terkhir ini muncul usaha selepan/mesin pengupas padi keliling. Munculnya usaha ini untuk mempermudah petani menggiling/ memisahkan beras dengan kulit tanpa harus bersusah payah dalam masalah pengangkutan. RMU dimodifikasi dengan mobil pengangkut sehingga dapat dibawa keliling mendekati lokasi pemilik gabah. Adanya penggilingan padi keliling ini mengancam usaha penggilingan padi statis yang lebihbesar (duduk) karena petani lebih memilih penggilingan padi yang lebih mudah. ${ }^{36}$

Setelah melakukan pengamatan dan wawancara dengan masyarakat Desa Gegeran dan juga orang yang melakukan praktik penggilingan padi keliling, bahwasannya praktik jasa penggilingan padi keliling sudah ada sejak belasan tahun yang lalu dan kegiatan tersebut sudah menjadi kebiasaan masyarakat Desa Gegeran.

Dalam wawancara yang penulis lakukan di rumah Bapak Jemari, selaku pemilik penggilingan padi keliling yang beroperasi di Desa Gegeran. Beliau biasanya beroperasi datang dari rumah ke rumah untuk mengambil padi milik petani dan langsung melakukan proses selep didepan rumah masing-masing pemilik gabah/padi. ${ }^{37}$

Komponen penerimaan pada usaha penggilingan padi keliling meliputi: penerimaan jasa penggilingan yang diperoleh dari rata-rata gabah yang digiling dikalikan dengan ongkos giling, penerimaan katul, dan penerimaan lain yang diperoleh dari bagi hasil jasa penggilingan yang dioperatori oleh orang lain. Ongkos giling yang diberikan oleh penggilingan padi keliling menggunakan satuan karung, bukan kilogram. ${ }^{38}$ Rata-rata ongkos giling per karung adalah Rp 12.000/karung Urea, dan sekitar Rp 15.000 sampai Rp 20.000 untuk karung besar

35 Kusno.. 97

${ }^{36}$ Kusno.320-323.

37 Wawancara Dengan Pemilik Penggilingan Padi Keliling.

${ }^{38}$ Amalia Nadifta Ulfa dan Masyhuri Masyhuri, "Analisis Ketahanan Pangan Rumah Tangga Di Kabupaten Lampung Tengah,” Jurnal Ekonomi Pertanian dan Agribisnis 3, no. 2 (1 April 2019): 233-43, https://doi.org/10.21776/ub.jepa.2019.003.02.2.233-243 
(50 kilogram). Dengan ketentuan seluruh hasil penggilingan diberikan kepada pemilik padi/gabah.

Dalam hal ini sudah dijelaskan bahwasannya hasil yang didapatkan dari proses penggilingan adalah hak dari petani, jadi dapat diartikan bahwa bekatul hasil penggilingan padi bukanlah lagi menjadi upah penggilingan dikarenakan telah terjadi kenaikan upah.

Banyak petani yang meresahkan pengambilan bekatul tersebut. Karena di perjanjian awal dari penambahan upah, tidak adanya pengambilan bekatul tambahan menjadi salah satu alasan petani menyetujuinya. Namun hal tersebut dilanggar oleh pemilik penggilingan dan mengakibatkan ketidak relaan salah satu pihak.

Para petani mempermasalahkan pengambilan bekatul tambahan upah tersebut, namun hal pengambilan bekatul memang sudah menjadi kebiasaan masyarakat Gegeran. Jadi tergantung ingin brkatulnya utuh dengan ditunggu, atau kehilangan sedikit bekatul dengan tidak ditunggu oleh petani, meskipun demikian transparansi dalam proses penggilingan padi di Desa gegeran sangatlah diperlukan, agar tidak ada kesalah pahaman sepihak.

\section{ANALISIS UPAH DAN AKAD JASA PENGGILINGAN PADI KELILING DESA GEGERAN PERSPEKTIF HUKUM ISLAM}

Berdasarkan penelitian yang dilakukan oleh peneliti dilapangan, sistim pengupahan yang dilakukan memiliki berbagai macam kebijakan yakni upah yang dipatok dalam upah jasa penggilingan padi ini masih Rp. 5000/karung (urea) ditambah 1 Gayung bekatul, namun karena saat itu mengalami krisis bahan bakar, tarif jasa penggilingan juga mengalami kenaikan upah menjadi Rp. 8000/karung (urea) bahkan ada beberapa yang menerapkan tarif Rp. 10.000/karung (urea) ditambah 1 gayung bekatul. karena ketidak samarataan upah, masyarakat tentunya lebih banyak memilih jasa yang nominal upahnya lebih murah dan juga tidak menginginkan hilangnya 1 gayung bekatul. Dengan masalah demikian para pemilik penggilingan padi memberikan tarif upah tetap yakni Rp. 12.000/karung (urea) . Dengan ketentuan semua hasil proses penggilingan diberikan kepada petani. Namun para pemilik penggilingan padi sampai saat ini masih mengambil bekatul yang seharusnya milik penuh petani, jika petani menunggu proses 
penggilingan petani akan mendapatkan penuh bekatul dan jika proses penggilingan ditinggan maka bekatul akan diambil oleh pemilik mesin penggilingan.

Penetapan upah adalah imbalan atau upah yang diterima oleh orang yang menyewakan sesuatu dari penyewa. Harga sewa atau upah harus diketahui meskipun terutang dalam tanggungan, barang-barang yang ditakar atau ditimbang dan barang-barang yang dapat dihitung. Karena itu harus dijelaskan jenis, macam, sifat dan ukurannya. Harga sewa atau upah harus dibayar sesuai dengan ketentuan dalam akad, sebagaimana penyewa juga harus mendapatkan manfaat dari barang yang disewa. Apakah harga sewa atau upah harus dibayar terlebih dahulu, di awal ataukah dibayarkan di akhir. Dibayar tunai ataukah diangsur, hal tersebut dapat disyaratkan dalam perjanjian. Jadi, harga sewa atau upah dalam perjanjian ijärah harus diketahui dengan jelas untuk menghindari terjadinya perselisihan.

Sedangkan dalam praktiknya, pada sewa jasa penggilingan padi keliling memiliki ketetapan upah sewa yakni Rp 8000/karung (urea) ditambah 1 gayung bekatul, namun terdapat perbedaan tarif di antara penggilingan padi keliling, yakni sebagian penggilingan padi menetapkan Rp 10.000/karung (urea) ditambah 1 gayung bekatul. Namun perbedaan harga tersebut menyebabkan komplain di antara petani. Kemudian pemilik penggilingan padi mendirikan organisasi penggilingan padi untuk menentukan harga sekaligus mematenkan harga. Dan disepakati yakni dengan harga Rp 12.000/karung (urea) tanpa mengambil 1 gayung bekatul. Namun, dalam praktiknya penggilingan padi keliling masih mengambil bekatul tersebut meskipun sudah membayar upah dengan harga Rp. 12.000/karung (urea) dengan ketentuan petani tidak menunggu sampai proses penggilingan selesaai.

Pemilik penggilingan padi keliling di Desa Gegeran tidak melaksanakan kesepakatan awal pengupahan. Padalah pemasangan tarif upah tersebut ditentukan sepihak oleh pemilik penggilingan padi. Hal itu dikarenakan persaingan usaha dan menyebabkan menurunnya pendapatan keseharian pemilik penggilingan. Pendapatan per hari pemilik penggilingan padi tidak menutup biaya transportasi, pekerja dan juga tenaga. Hal ini jelas merugikan petani atau konsumen. Meskipun demikian, tidak ada pihak yang dipaksa untuk menerima 
harga/tarif tersebut, dan petani (konsumen) menyetujui harga/upah selep tersebut karena sebagai orang awam masyarakat mempercayakan semuanya kepada pemilik selep

Dalam melakukan usaha apapun itu jenis usahanya, persaingan usaha itu wajar, justru hal itu bisa menjadi penyemangat perkembangan usahanya untuk memberikan pelayanan sebaik mungkin. Dalam menjalankan suatu usaha harus adanya transparansi dan tidak adanya kerugian satu pihak serta untuk menghindari terjadinya perselisihan.

Dalam penentuan upah, Mengingat bahwa sebuah transaksi dapat dikatakan sah apabila dilakukan atas dasar saling ridha di antara kedua belah pihak, maka perlunya dilakukan dengan adil atau atas dasar suka sama suka diantara kedua belah pihak.

Dari penelitian di atas dapat diambil kesimpulan bahwa sistim pengupahan jasa penggilingan padi keliling di desa Gegeran belum sepenuhnya sesuai dengan hukum Islam, karena penetapan upah hanya dilakukan oleh salah satu pihak dan pengambilan penambahan upah dengan bekatul tanpa adanya transparansi dari pihak petani, sehingga merugikan salah satu pihak yakni petani atau konsumen.

Usaha jasa penggilingan padi keliling merupakan kategori bisnis usaha yang dalam pemahaman fiqh muamalah disebut dengan Ijarah. Ijarah adalah pemanfaatan sesuatu yang dikehandaki dan diketahui, dengan memungut imbalan (uang sewa) yang ditentukan, dan penyewa boleh menggantikan pemanfaatan tersebut kepada orang lain. Ijarah merupakan salah satu bentuk perikatan atau perjanjian dalam Islam. Perjanjian dalam islam biasa disebut dengan akad. Adapun pengertian akad adalah suatu perikatan antar ijab dan qabul dengan cara yang dibenarkan syara' yang menetapkan adanya akibat-akibat hukum pada objeknya. Dalam akad pada dasarnya dititik beratkan pada kesepakatan antara dua belah pihak yang ditandai dengan ijab qabul.

Bentuk ijarah penggilingan padi keliling adalah bentuk Ijārah dzimmah. Bentuk ijarah ini adalah ijarah dengan obyek berupa jasa orang atau manfaat dari mesin penggilingan yang berada dalam tanggungan pemilik mesin penggilingan yang bersifat tidak tertentu secara fisik. Artinya pemilik mesin penggilingan padi 
memiliki tanggungan untuk memberikan layanan jasa atau manfaat yang disewa petani, tanpa terikat dengan orang atau barang tertentu secara fisik.

Dalam kontrak ijārah dzimmah, apabila terdapat cacat pada mesin penggilingan padi, tidak menetapkan hak khiyar bagi petaani. Demikian juga apabila mesin penggilingan padi mengalami kerusakan di tengah kontrak, akad ijärah tidak batal. Artinya, pemilik mesin penggilingan tetap memiliki tanggungan untuk memberikan layanan jasa atau manfaat sesuai perjanjian hingga kontrak selesai. Sebab, ijārah tidak bersifat tertentu pada obyek yang mengalami kerusakan, melainkan obyek yang berada dalam tanggungan pemilik mesin penggilingan, sehingga pemilik mesin penggilingan berkewajiban mengganti proses penggilingan secara maksimal.

Dan ketika pihak pemilik mesin penggilingan tidak sanggup memberikan ganti, petani baru memiliki hak khiyar. Syarat ijärah dzimmah:

a. Upah harus diserahkan-terimakan secara tunai di majelis akad. Pemberian upah dalam penggilingan padi ini dilaksanakan di akhir proses penggilingan padi. Yakni Rp12.000/karung (urea).

b. Menyebutkan kriteria barang yang dijadikan objek sewa. Dalam hal ini, dalam hal ini adalah mesin penggilingan padi keliling sebagai barang atau objek sewa dan juga padi sebagai alat pengambil manfaat atas jasa.

Masyarakat Gegeran biasa memanfaatkan mesin penggilingan padi keliling untuk mengupas kulit gabah (selep) menjadi beras, yang mana beras tersebut merupakan kebutuhan pokok bagi masyarakat. Di dalam praktik jasa penggilingan padi keliling ini masyarakat pemilik mesin penggilingan padi beroperasi keliling, bagi masyarakat yang ingin menyelepkan gabah, bisa menunggu jasa pengilingan padi beroperasi atau masyarakat yang sudah berlangganan bisa langsung menghubungi pihak jasa penggilingan padi untuk datang ke rumah guna melakukan penyelepan. Dalam transaksi penyelepan padi/gabah tersebut tidak dilakukan secara tertulis, tetapi dilakukan secara lisan.

Dalam hal ini peneliti menganalisis akad penggilingan padi yang ada di desa Gegeran menggunakan teori akad dalam hukum Islam, khususnya tentang ketentuan-ketentuan asas perjanjian dalam Islam. 
a. Asas Ibahah adalah asas umum hukum Islam dalam bidang muamalat secara umum asas ini dirumuskan berdasarkan kaidah fiqh: "pada asasnya segala sesuatu itu boleh dilakukan sampai ada dalil yang melarangnya. ${ }^{39}$ Asas ini merupakan kebalikan dari asas yang berlaku dalam masalah Ibadah. Dalam hukum Islam untuk tindakan-tindakan Ibadah berlaku asas bahwa bentukbentuk Ibadah yangsah adalah bentuk-bentuk yang disebutkan dalam dalil-dalil syari'ah. Sedangkan, dalam tindakan-tindakan muamalat berlaku asas sebaliknya, yaitu bahwa segala sesuatu itu sah dilakukan sepanjang tidak ada larangan tegas atas tindakan itu. Pada praktiknya dalam sistim pembayaran uang saja sebagai alat transaksi pembayaran tetapi dalam hal ini pemilik penggilingan padi mengambil bekatul sebagai upah tambahan. Upah tambahan tersebut akan diambil jika petani tidak menunggu sanpai proses akhir dan akan memiliki hak penuh bekatul jika proses penggilingan ditunggu oleh petani.

b. Asas konsesualisme, bahwasannya setiap perjanjian atau perikatan didasarkan atas kesepakatan bersama antara kedua belah pihak yang melalukan perjanjian tersebut. Dalam transaksi penggilingan padi keliling ini penentuan tarif berupa uang dilakukan secara sepihak yakni oleh pemilik mesin penggilingan padi sendiri. Dalaam hal pengaambilan bekatul juga dilakukan sepihak, meskipun masyarakat mengetahui bahwa pengambilan bekatul sebagai tambahan upah, namun hal tersebut tidak dibenarkan karena masyarakat sudah memebayar dengan penuh tarif yang ditentukan yakni Rp 12.000/karung (urea) tanpa mengurangi bekatul. Namun hal tersebut sudah menjadi kebiasaan masyarakaat Gegeran pada umumnya.

c. Asas keadilan dan keseimbangan prestasi merupakan asas yang menegakkan pentingnya kedua belah pihak agar tidak saling merugikan. Transaksi harus didasarkan keseimbangan antara apa yang dikeluarkan oleh satu pihak dengan apa yang diterima.

Pada praktiknya dalam pengambilan bekatul dilakukan sepihak yakni oleh pemilik penggilingan padi. Sehingga petani atau konsumen tidak mengetahui secara pasti hal tersebut . dalam teori keadilan dijelaskan bahwa suatu

${ }^{39}$ Syamsul Anwar....., 83 
transaksi harus didasarkan keseimbangan antara apa yang dikeluarkan oleh satu pihak dengan apa yang diterima. Sedangkan pada praktiknya pengambilan upah berupa bekatul dilakukan secara sepihak. Padahal bekatul sudah bukanlah sebagai tambahan upah yang seharusnya diambil oleh pemilik penggilingan. Sehingga transparansi dalam pengambilan upah ini sangatlah penting dan seharusnya tidak dilakukan. Dalam prakteknya pengambilan penambahan upah dengan bekatul tersebut tidak didasarkan pada keseimbangan dan keadilan, yang mana hal tersebut merupakan asas yang menegakkan pentingnya kedua belah pihak agar tidak saling merugikan.

d. Kemudian asas amanah (kejujuran), dalam transaksi penggilingan padi tidak disertakan nota pembayaran sebagai bukti transaksi, dan untuk pengambilan penambahan upah berupa bekatul dilakukan sepihak yakni oleh pemilik mesin penggilingan padi, syang mana masyarakat tidak seharusnya memberikan upah tambahan berupa bekatul terhadap pemilik penggilingan. Meskipun dalam hal ini masyarakat sudah memepercayakan kepada pemilik mesin

Pada transaksi jasa penggilingan padi keliling, pembayaran dialakukan di akhir, yang mana ongkos selep ditentukan oleh pemilik mesin. Akad penggilingan padi hanya menyebutkan keinginan penguna jasa untuk menyelepkan gabahnya. Pada akad tersebut tidak disebukan ketentuan-ketentuan mengenai kepemilikan bekatul, karena hal itu sudah menjadi kebiasaan bahwa pemilik sah bekaatul adalah milik penuh petani atau konsumen. Dalam muamalah, sahnya transaksi berdasarkan kesepakatan kedua belah pihak penjual dan pembeli yang saling merelakan satu sama lain, sehingga tidak ada yang dirugikan. Serta kesepakatan yang ditempuh tanpa ada unsur paksaan. Dalam hal tersebut sudah jelas pemilik penggilingan padi mengambil bekatul tanpa sepengetahuan petani padahal sudah jelas ketentuan-ketentuan mengenai tarif penggilingan padi bahwasanya ketika masyarakat sudah membayar Rp 12.000 masyarakat tidak harus menambah bekatul sebagai biaya tambahan. Namun hal pengambilan bekatul tersebut sudah menjadi kebiasaan desa Gegeran dan apabila petani tidak ingin kehilangan bekatulnya, petani harus menunggu proses penggilingan sampai selesai, dan apabila petani tidak menunggu proses penggilingan, secara otomatis petani merelakan kehilangan bekatul tersebut dan mendasarkannya atas kepercayaan. 
Dalam melakukan suatu transaksi tidak harus secara tertulis, seperti halnya dalam praktik penggilingan padi keliling di Desa Gegeran Kecamatan Sukorejo Kabupaten Ponorogo. Dalam praktiknya transaksi tersebut tidak disertakan nota atau kuitansi sebagai alat bukti pembayaran. Menurut penulis apabila dalam transaksi tersebut dilakukan secara tertulis seperti adanya total pembayaran hanya akan membuat ribet karena memakan waktu. Sedangkan petani sebagai konsumen menginginkan proses yang cepat dan praktis. Sehingga bagaimana pun bentuk transaksi akadnya sah-sah saja selama tidak aa dalil yang melarangnya. Hanya saja dalam pengambilan upah tambahan berupa bekatul, pihak penggilingan sehausnya tidak melakukan hal tersebut. Karena petani sudah membayar upah sebagaimana yang sudah dimaksudkan tanpa pengambilan upah tambahan yakni bekatul. Meskipun masyarakat Gegeran/konsumen mendasarkan semua pada kepercayaan, tetapi transparansi sangat penting mengingat upah tambahan bekatul merupakan jenis barang yang tidak seharusnya dipakai untuk upah tambahan.

\section{PENUTUP}

Berdasarkan hasil penelitian dan pembahasan yang telah dilakukan oleh peneliti, maka dapat diambil kesimpulan sebagai berikut: Pertama, Dari penelitian di atas dapat diambil kesimpulan bahwa sistim pengupahan jasa penggilingan padi keliling di Desa Gegeran belum sepenuhnya sesuai dengan Akad Ijarah, karena penetapan upah hanya dilakukan oleh salah satu pihak dan pengambilan penambahan upah dengan bekatul tanpa adanya transparansi dari pihak petani, sehingga merugikan salah satu pihak yakni petani atau konsumen. Kedua, Berdasarkan praktik yang ada, penulis dapat mengambil kesimpulan bahwa akad jasa penggilingan padi keliling di Desa Gegeran Kecamataan Sukorejo Kabupaten Ponorogo belum sepenuhnya sesuai dengan Akad Ijarah karena dalam transaksi tersebut tidak memenuhi asas-asas dalam berakad, khususnya asas ibahah, asas amanah (kejujuran), keadilan dan keseimbangan prestasi. Meskipun dalam transaksi antara keduanya terdapat ijab qabul yang sah. 


\section{DAFTAR PUSTAKA}

Afrizal. "Tinjauan Hukum Islam Tentang Pengupahan Penggilingan Padi Dengan Beras." Skripsi, Universitas Islam Negeri Raden Intan Lampung, 2017. http://repository.radenintan.ac.id/3100/.

Andri Soemitra. Hukum Ekonomi Syariah Dan Fiqh Muamalah Di Lembaga Keuangan dan Bisnis Kontemporer. Jakarta Timur: PRENADA MEDIA GROUP, 2019.

Anwar, Syamsul. Hukum Perjanjian Syariah. Jakarta: Rajawali Press, 2010.

Anwariyah. wawancara dengan pemilik padi atau gabah padi keliling di Desa Gegeran, 29 Juli 2020. Desa Gegeran.

Fatimah, Siti. Wawancara Dengan Pemilik padi atau Gabah, Agustus 2020. Desa Gegeran.

Huda, Qomarul. Fiqih Muamalah. Yogyakarta: Teras, 2011.

Insawan, Husain. "Al-Ijarah dalam perspektif Hadits, Kajian Hadits dengan Metode Maudhu'iy." Fakultas Ekonomi dan Bisnis Islam IAIN Kendari 2, nomor 1 (Juni 2017). https://garuda.ristekbrin.go.id/documents/detail/2041350.

Izzudin Karimi, Tim Ulama. Fikih Muyassar Panduan Praktis Fikih dan Hukum Islam. 387. Jakarta: Tim Darul Haq, 2019.

Jemari. Wawancara Dengan Pemilik Penggilingan Padi Keliling, Oktober 2020. Desa Gegeran.

Kartikasari, Ratna. "Tinjauan Hukum Islam Terhadap Praktek Jasa Penggilingan Padi Keliling Di Desa Purworejo Kecamatan Geger Kabupaten Madiun." Skripsi, Sekolah Tinggi Agama Islam Negeri (STAIN) Ponorogo, 2016.

Kusno, Hadiutomo. Membangun Kawasan Persawahan Padi Modern. Bogor: PT Penerbit IPB Press, 2019. https://www.google.co.id/books/edition/Membangun_Kawasan_Persawah an_Padi_Modern/E6PVDwAAQBAJ?hl=id\&gbpv=1\&dq=Hadiutomo,+Kusno. Membangun+Kawasan+Persawahan+Padi+Modern\&printsec=frontcover.

Novi Dewi, Sartika, dan Zuhriyah Ramdhani. "Kajian Penggunaan Mesin Penggiling Mobile Terhadap Mutu Beras Untuk Beberapa Varietas Padi Di Kabupaten Sumbawa Barat." Jurnal Ilmiah Rekayasa Pertanian dan Biosistem, 6 (1 Maret 2018). https://doi.org/10.29303/jrpb.v6i1.72.

Santoso, Lukman. Hukum Perikatan. Malang: Setara Press, 2016.

setiawan, johan, dan Albi Anggito. Metode Penelitan Kualitatif. Jawa Barat: CV Jejak, t.t.

Sonata, Depri Liber. "METODE PENELITIAN HUKUM NORMATIF DAN EMPIRIS: KARAKTERISTIK KHAS DARI METODE MENELITI HUKUM." FIAT JUSTISIA:Jurnal Ilmu Hukum 8, no. 1 (5 November 2015). https://doi.org/10.25041/fiatjustisia.v8no1.283.

Suhendi, Hendi H. Fiqh Muamalah: Membahas Ekonomi Islam Kedudukan Harta, Hak Milik, Jual Beli, Bunga Bank Dan Riba, Musyarakah, Ijarah, Mudayanah, Koperasi, Asuransi, Etika Bisnis Dan Lain- Lain. Jakarta: PT RajaGranfindo Persada, 2002.

Ulfa, Amalia Nadifta, dan Masyhuri Masyhuri. "Analisis Ketahanan Pangan Rumah Tangga Di Kabupaten Lampung Tengah." Jurnal Ekonomi Pertanian dan Agribisnis 3, no. 2 (1 April 2019): 233-43. https://doi.org/10.21776/ub.jepa.2019.003.02.2. 


\section{Jurnal Antologi Hukum}

Vol. 1, No. 1, Juli 2021

Zuhaili, Wahbah. Tafsir Al-Munir. Juz 5 \& 6. Jakarta: Gema Insani, 2016. https://id1lib.org/book/5228264/2a9ad4?dsource=recommend.

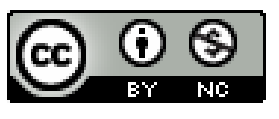

(C) 2021 by the authors. Submitted for possible open access publication under the terms and conditions of the Creative Commons Attribution-NonCommercial 4.0 International License (CC BY NC) license (https://creativecommons.org/licenses/by$\mathrm{nc} / 4.0 /)$. 